\title{
"Listening is Hard": ADDIE Model on the Development of English Listening Worksheets
}

\author{
Dewi Furwana \\ IAIN Palopo \\ dewi_furwana@iainpalopo.ac.id \\ Andi Tenrisanna Syam \\ IAIN Palopo \\ anditenrisannasyam86@gmail.com
}

\begin{abstract}
The authors' pre-observation showed that when students learn listening skills, the students faced some difficulties. The students found difficulty expressing their ideas because they found many complex vocabularies, the audio text uses advanced grammar, and the native speaker speaks too fast. Therefore, to solve those students' problems, the authors proposed to develop the appropriate listening worksheet for the English education study program of IAIN Palopo. Then, the authors applied Research and Development method and used the ADDIE model. 18 students of the English education study program IAIN Palopo were involved as the research subject. The research instruments used were observation and questionnaire. From observing, analysing students' needs, developing the materials, evaluating expert judgments, conducting try-out materials, revising the product, the final product of this study is listening worksheets stored in a compact disc. The worksheets consist of a course grid, learning objective, language note, pre-activity, whilst-activity and post-activity. The authors expect that this worksheet will be useful for EFL teachers whose students' listening skills are still below the expected level of competence.
\end{abstract}

Keywords: ADDIE model, listening skill, worksheet

\section{INTRODUCTION}

Listening practices have some benefits in language learning. First, listening provides students with an example of proper English pronunciation. It also makes it easier for them to develop their other abilities. Second, by getting a listening skill, the learners can study some language elements indirectly. Those elements could be words pronunciation, language speed, language stressing, language accent, and language intonation. Those elements will be beneficial to increase learners' capability to communicate effectively in English. This is supported by Yildirim \& Yildrim's (2015) statement that "Listening is important in both everyday life and academic settings because people need to maintain successful communication." Since listening is so important in language learning and teaching, we must encourage our students to practice their listening skills both within and outside of the classroom. Finally, it helps students to learn grammar indirectly. When students are introduced to the English language, they master the grammar without even understanding it. They can learn to know when to use proper grammar if they listen to spoken texts regularly.

Some students improve their listening skill naturally, but others face difficulty to do it (Gilakjani \& Sabouri, 2016). Achieving listening skills may even be stressful for the students of the English education study program of IAIN Palopo. Based on pre-observation, they experienced troubles in the listening comprehension course. There are still many unfamiliar vocabulary for students. The textbook used by them has an uncommon theme and contains different cultural topics of learning such as city transportation, celebration, restaurant, and touring a city. Those topics are different because the book offers overseas culture and audio rhythm. Besides, students' capability and level of the book are also different. The students challenge to pass the 
exercises because the audio materials are inappropriate for them.

Realizing the statements above, the authors were interested in developing listening materials in the forms of the worksheet and compact disc. According to Tomlinson (2011), materials are everything that can be used by teachers and learners to support language learning. The materials can be in the form of TV news, a printable worksheet, a CD Room, a DVD, a YouTube video, an online audio and video news (Peterson, 2011), an e-book, etc. These materials are beneficial to improve students' listening knowledge. According to Hamdani (2011, p.122) "learning material ease teachers to implement learning. The teacher as a facilitator in learning activities will be more comfortable because the learning materials are compiled by themselves and delivered in various ways."

According to Ahmadi (2016), teachers must facilitate the students with suitable materials and exercises to comprehend the English language. Proper listening comprehension training can minimize listening anxiety and provide a rational framework for students to become independent learners who can effectively use the listening process to learn. Amila et al. (2018) argued that teachers must have the ability to create a variety of teaching materials so that learning process does not become monotonous and repetitive for students.

A worksheet is a medium for getting students to respond to a teacher. Many studies have discussed the effectiveness of worksheets. Rahayu et al. (2018), Yulkifli et al. (2019) stated that the student's worksheet is a type of teaching material that can provide students with a useful activity to practice. A student worksheet is a teaching tool that includes a series of exercises aimed at improving students' comprehension, skill, and competence. According to Zulyadaini (2017), “Students' worksheets are instructional materials printed on sheets of paper that contain materials, summaries, and directions for the execution of learning tasks that must be completed by learners and that relate to the essential competencies that must be attained." A student worksheet may be thought of as a source of learning that consists of sheets containing brief content, learning goals, guidelines for answering questions, and a number of questions that students must answer (Ikhsan \& Handayani, 2016).

The materials writing method, according to Tomlinson (2011), have seven stages. The phases are: defining a material requirement, exploring the need, contextualizing materials, pedagogically contextualizing materials, manufacturing materials, student usage of materials, and assessing materials against agreed-upon objectives. Sinaga and Fitriyani (2019) argued that developing teaching materials need the process of adapting, supplementing, and elaborating them to ensure that they meet the needs of students in learning a subject. The steps in the preparation of worksheets according to the Ministry of National Education (2008) are as follows: (1) analyze curriculum; (2) compile the needs of the students' worksheets; (3) determine the worksheet titles; (4) arrange student worksheets, student worksheets can be done in the following steps: (a) formulating basic competencies (b) determine the means of production; (c) compiling materials; (d) paying attention to the structure of teaching materials; (e) taking into account the various didactic requirements, construction, and technical conditions.

Several scholars have developed listening worksheet such as Nawangsasi (2015), Qodir et al. (2016), Syafi'i (2016) has resulted in the final product in the form of the compact disc, recorded materials, a lecturer's guide, and a worksheet. Adnan (2014) has produced listening materials and she also explored the obstacles faced by 'PPG SM$3 \mathrm{t}^{\prime}$ on developing it. Zaenuri (2008) made a listening worksheet for Islamic Junior High School students. Karim and Ciptaningrum (2019) made multimedia-based listening materials for the tenthgraders of MAN 1 Pamekasan. Kuswardani et al. (2015) produced learning materials based on CTL approach.

Considering the statements above, the authors tried to develop a listening worksheet by ensuring that the consistency of the audio material is reasonable, getting the guidance of repetition in each listening activity, publishing remarks words once students have completed the task successfully, 
providing different exercises to prevent students from being bored, and recommending some activities that the lecturer can do in the classroom.

\section{METHODOLOGY}

To develop the listening materials, the authors adopted the ADDIE model. ADDIE stands for analyzing, designing, developing, implementing, and evaluating. The authors used the ADDIE model because according to Syam (2020, p.20), the ADDIE model is a common and compatible learning model applied for development research. Besides, it is a model that provides an opportunity to do continuous evaluation and revision in each phase passed. So that the resulting product becomes a valid and reliable product. ADDIE model is very simple but the implementation is systematic. Addie is an acronym for the five stages of a development process: Analysis, Design, Development, Implementation, and Evaluation. The procedures of the ADDIE model were described as follows:

\section{a. Analysis}

This step is the first schema in the ADDIE model. In analysis, the authors divided a questionnaire that contained lack, wants, and necessity questions. (Nation \& Macalister, 2010). It aims to know students' learning needs and learning targets.

\section{b. Design}

In the ADDIE Model, making a plan is called design. In this step, the authors focused on designing a course grid (lesson plan) for the students considering the data gotten in need of analysis.

c. Development

In this step, the authors passed four ways before implementing the worksheet. Those are, first, list some activities that could be appropriate for the learners to be learned. Second, develop a procedure of delivering the listening material for the students based on learners' needs and the goals also objectives of the course. Third, organizes the materials, fourth, validates the materials to experts to make sure whether the material is matched to the students' needs as well as the goals and objectives of the course or not. Finally, the worksheet is ready to be implemented.

d. Implementation. In this step, the product is going to be implemented in the class.

e. Evaluation

The authors evaluated the findings of tryout by using two kinds of evaluation. They were formative and summative evaluations. The formative evaluation would be evaluated during and between the ADDIE steps, and summative evaluation would be used in the implementation (try-out) steps.

The participants of this research were 18 English education study program students in the second semester. Eighteen students also were involved in product try-out.

The instruments of this research were questionnaires. The authors gave questionnaires to know their lack, want, and necessity. The expert judgments and the students who joined the product try-out have also filled the questionnaires. In this research, the data collected from need analysis and experts' judgment would be analyzed qualitatively quantitatively. The data from the expert and try-out were noted well as the attachment for the authors in developing and revising the worksheet.

\section{RESULT AND DISCUSSION \\ The Results of Need Analysis \\ Necessities}

The first question is about what they need in listening skills. $78 \%$ of students answered that they want to analyze the sounds they heard so that the information will be understood. Then, $11 \%$ of students chose to listen to the full sounds from everyday stuff and $11 \%$ of students need activities that will improve their English ability.

The next question is their purposes in learning a listening comprehension subject. 59\% of students need to listen to the English dialogue (59\%). They do not need to improve their TOEFL score. $23 \%$ of students need to know the correct pronunciation in every word and $18 \%$ of students need to improve their accent ability in English.

\section{Lacks}


The data relating to the lack of students shows that the mastery rate of English department students is in basic lower $27.8 \%$, basic upper $38.9 \%$, intermediate lower $11.1 \%$, intermediate upper $16.7 \%$, and advanced $0 \%$.

The students' TOEFL score is less than 424 $(33.3 \%)$, less than $500(11.1 \%)$, and never got the test obviously ( $50 \%)$. Some difficulties faced by the students when they learn a listening comprehension subject, namely, the students were difficulty expressing their ideas because they found many difficult vocabularies $(44.4 \%)$, the audio text uses idiom language (11.1\%), the audio text is too long $(16.7 \%)$, and the audio text uses advanced grammar (16.7\%). The students are difficulty understanding the audio because the native speaker speaks too fast $(35 \%)$, the sounds spoken by the speaker are unclear $(65 \%)$, and the students cannot see the speaker's expressions $(0 \%)$.

\section{Wants}

The data shows that $50 \%$ of students wanted to improve their listening skill by using " the fastest the winner" method to gain the higher score, $27.8 \%$ of students wanted to answer the questions by turning the text to the students, and $22.2 \%$ of students wanted to write or retell the voice. $38.9 \%$ of students' chose study sequences are listening, speaking, reading, and writing. $22.2 \%$ of students chose listening, reading, speaking, and writing. $11.1 \%$ of students chose speaking listening, reading, and writing. No one chose speaking, reading, writing, and listening.

The next question is how long the text they wanted to hear. $25 \%$ of students wanted to have a length of the text about 300 words, $25 \%$ of students wanted a text that contains 300 words include the pictures or diagram, $25 \%$ of students wanted a text that contains 200 to 250 words, and $25 \%$ of students wanted a text contains 150 to 200 words include the pictures or diagram.

Furthermore, the students answered about what is the most difficult thing in listening. 53\% of students answered about the most difficult thing in listening is they did not understand what native speaker says because they were lack vocabularies, $47 \%$ students prefer to identify the keywords through the oral description, and the other option $0 \%$.

$44.4 \%$ of students wanted to listen to the monologue and dialog text then they will retell what they heard, $38.9 \%$ of students wanted to listen then answer the following questions, and other option $0 \%$.

Lastly, the students answered about what is their favorite topics in listening. $50 \%$ of students wanted to listen to the topics about daily activities, $21 \%$ of students chose education, $29 \%$ of students chose culture, and other option $0 \%$.

\section{Result of Experts' Validation}

Regarding the language aspect, four aspects were judged. They were: (1) the language level is suitable with the students' development, language clarity, and comprehensibility, (2) the language suitability used in material explanation, (3) task direction suitability with the student's cognitive development, and (4) the correctness of language used. The results of experts' judgment were shown in the following table:

Table 1. Language Aspect Assessment

\begin{tabular}{lll}
\hline Aspects to be assessed & Means & Category \\
\hline $\begin{array}{l}\text { The suitability of the language level } \\
\text { with the students' development }\end{array}$ & 4.3 & Excellent \\
\hline Language is clear and comprehensible & 4.6 & Excellent \\
\hline $\begin{array}{l}\text { The suitability of language used in } \\
\text { explanation and tasks direction with } \\
\text { the students' cognitive development }\end{array}$ & 4.6 & Excellent \\
\hline $\begin{array}{l}\text { The language used grammatically } \\
\text { correct }\end{array}$ & 3.5 & Good \\
\hline
\end{tabular}


Generally, the experts stated that the language used in the worksheet was good for listening activities in the class.

Regarding the content materials of the worksheet, the experts agreed that content materials were good for the students. According to Qodir et al. (2016), "The content should pique the students' attention and inspire them to listen. Funny stories and funny illustrations can have a big impact on language learning, but they shouldn't be the only form of material used. Furthermore, not only should the content be fascinating to carry out the listening work, but lecturers should also be imaginative so that students enjoy themselves what they do." The results of experts' judgment were shown in the following table:

Table 2. Content Materials Assessment

\begin{tabular}{lcc}
\hline Aspects to be assessed & Means & $\begin{array}{l}\text { Experts' } \\
\text { Statement }\end{array}$ \\
\hline $\begin{array}{l}\text { Worksheet developed in accordance } \\
\text { with learning objectives }\end{array}$ & 4 & Excellent \\
\hline $\begin{array}{l}\text { Worksheet developed in accordance } \\
\text { with the students' need in learning } \\
\text { listening I course }\end{array}$ & 4.6 & Excellent \\
\hline $\begin{array}{l}\text { The worksheet developed exploring a } \\
\text { lot of text related to students' daily life }\end{array}$ & 4 & Excellent \\
\hline $\begin{array}{l}\text { The worksheet was developed } \\
\text { elaborating the text in detail }\end{array}$ & 4 & Excellent \\
\hline $\begin{array}{l}\text { In general, the worksheet provided a } \\
\text { clear explanation }\end{array}$ & 4.3 & Excellent \\
\hline Audio-material contains pronunciation & 4.3 & Excellent \\
\hline $\begin{array}{l}\text { The texts given in the material can help } \\
\text { students understand the main topic }\end{array}$ & 4.6 & Excellent \\
\hline $\begin{array}{l}\text { Teaching materials (text, tables, } \\
\text { pictures, etc.) were taken from sources } \\
\text { relevant to the topic being discussed }\end{array}$ & 4.3 & Excellent \\
\hline $\begin{array}{l}\text { Teaching materials (text, tables, } \\
\text { pictures, attachments, etc.) are taken } \\
\text { from up-to-date sources }\end{array}$ & 4 & Excellent \\
\hline $\begin{array}{l}\text { The material developed consistently } \\
\text { presented pre-activity and main } \\
\text { activity on each unit }\end{array}$ & 4.6 & Excellent \\
\hline $\begin{array}{l}\text { The forms of tasks in each unit are } \\
\text { presented in various ways }\end{array}$ & 4.3 & Excellent \\
\hline
\end{tabular}

Concerning the worksheet layout, the experts agreed that the worksheet was excellent for the students. The results of layout aspects assessment could be seen in the following table:

Table 3. Layout of the Worksheet Assessment

\begin{tabular}{lll}
\hline Aspects to be assessed & Means & Category \\
\hline The placement of the layout elements & 4.3 & Excellent \\
\hline
\end{tabular}


(title, introduction, acknowledgment, table of contents) at the beginning of each chapter is consistent

\begin{tabular}{lll}
\hline $\begin{array}{l}\text { The placement of layout elements on } \\
\text { the page follow a consistent pattern }\end{array}$ & 4 & Excellent \\
\hline $\begin{array}{l}\text { The illustrations provided can enlarge } \\
\text { understanding of the information } \\
\text { conveyed }\end{array}$ & 4 & Excellent \\
\hline $\begin{array}{l}\text { The illustration given has a } \\
\text { proportional size so that it provides an } \\
\text { accurate picture of the object in } \\
\text { question }\end{array}$ & 4 & Excellent \\
\hline $\begin{array}{l}\text { In general, the illustrations are shown } \\
\text { in accordance with the topic of } \\
\text { discussion }\end{array}$ & 3.9 & Excellent \\
$\begin{array}{l}\text { The developed worksheet does not use } \\
\text { lots of fonts }\end{array}$ & 3.5 & Good \\
$\begin{array}{l}\text { The material uses letter variations } \\
\text { (bold, italic, capital) to distinguish } \\
\text { levels and emphasize the text that is } \\
\text { considered important }\end{array}$ & 4 & Excellent \\
\hline
\end{tabular}

\section{First Revised Product}

After validating the listening worksheet, then the authors obtained some corrections from the experts. These are the corrections from learning material experts and lay-out experts.

Table 4. Language Expert Correction

\begin{tabular}{ll}
\hline Point to be revised & Revision \\
\hline $\begin{array}{l}\text { Mistyping of words' spelling. For } \\
\text { example: "Senteces" }\end{array}$ & It should be Sentences \\
\hline $\begin{array}{l}\text { Improper picture illustration toward } \\
\text { the material }\end{array}$ & $\begin{array}{l}\text { Having another proper pictures and } \\
\text { make it relevant toward the material }\end{array}$ \\
\hline $\begin{array}{l}\text { Adding some keywords to remind } \\
\text { the students about the material }\end{array}$ & $\begin{array}{l}\text { Put some keywords in the end of } \\
\text { material }\end{array}$ \\
\hline $\begin{array}{l}\text { The illustration of the material } \\
\text { should be written manually }\end{array}$ & $\begin{array}{l}\text { Writing and drawing the material by } \\
\text { our own }\end{array}$ \\
\hline $\begin{array}{l}\text { The learning strategies should be } \\
\text { exist on the worksheet }\end{array}$ & $\begin{array}{l}\text { Adding some listening strategies on } \\
\text { the material }\end{array}$ \\
\hline Background and shape color & $\begin{array}{l}\text { Background must be changed based } \\
\text { on content of unit. The color also } \\
\text { should be more colorful and not } \\
\text { monotone. }\end{array}$ \\
\hline The details of picture & $\begin{array}{l}\text { It should be more attractive by } \\
\text { adding some details on the picture }\end{array}$ \\
\hline
\end{tabular}




\section{The Results of Field Try-out}

The worksheet was given to 18 secondsemester English Education students at IAIN Palopo. After doing the try-out, the authors spread the questionnaire to assess the true outcome of the worksheet. Since the students had

The students stated that the worksheet has many attractive pictures. Besides, the vocabularies used were understandable and the students are easy to find out the meanings of every word because the authors provided the key language in each unit (Syafi'i, 2016).

\section{DISCUSSION}

According to the authors' observation, despite English learning, most of the students in the second semester had low English proficiency although they have learned English since they were in elementary school. Their lack of English vocabulary, as well as a lack of confidence, may both lead to poor results. English encounters, low desire to learn, low self-confidence, and so on.

This research purposed to develop the appropriate listening worksheet for the English education study program of IAIN Palopo because worksheets can help students achieve academic success in a variety of ways. Worksheets, for example, may be used as additions to textbooks to provide material for specific classes. Furthermore, blanks in worksheets invite students to fill in the gaps; they provide opportunities for information construction. When combined with appropriate instructions, well-designed worksheet questions can pique students' interest (Lee, 2014).

One of the attempts that teachers make to boost the competence of students is to produce high-quality students' worksheets (Yulkifli, 2019). Layout is the foundation for effectively conveying a message to students (Lee, 2014). Rotter (2006) suggested the COLA (contrast, orientation, lettering, and artwork) layout principle to help teachers improve their worksheet design skills. The features of questions are also essential factors in worksheets. Calderhead et al. (2006) demonstrated that the order in which objects with varying levels of cognitive complexity are placed limited time, they could merely do some exercises, so the authors examined five of the 18 exercises as a representative of the try-out results. From five exercises, most of the students answered that they understood the material because the worksheet has been well-organized.

can influence students' learning outcomes. Educators are often concerned about the information formats, or scaffolds, in worksheets.

The authors did some steps to develop a listening worksheet. The steps were described as follows: first, the authors conducted need analysis in the form of questionnaires. The results of the needs survey revealed a clear desire for effective listening materials that taught students how to listen rather than only testing them. Second, the authors designed the course grid, and it consisted of four parts namely the title of the unit, warm-up, main activity, and follow-up. The worksheet contains 14 units and each unit consists of fourfive tasks.

Third, after the authors compiled the course grid, the authors were developing the listening materials. The title of each unit was written before a brief description of the unit content. The page was written at the bottom of the page. Some colorful pictures were provided to make the listening worksheet more attractive. The tasks were in the forms of multiple choices, fill in the blanks, match pictures with words, complete the forms, listen to the descriptive texts then number the pictures, classify the words based on their categories, etc.

Fourth, after the authors developed the listening worksheet, the expert then judged the product. There were three aspects assessed, namely language, content materials, and layout of the worksheet. Then, the authors revised the first listening worksheet draft based on the experts' judgment suggestions.

Fifth, the authors held a field tryout. 18 students participated. Regarding their answers on the questionnaire, the students stated that materials in the listening worksheet expose them to the real language, and it is more closely connected to everyday life activities. Hence, 
students find the worksheet more beneficial since it can be applied in their social life and more crucial to increase their communication and listening skills in the target language.

\section{CONCLUSION}

Based on the research results, the conclusions are then drawn. Firstly, the final product of this research is listening materials for the English education study program of IAIN Palopo. Learning materials are in the form of students' worksheets and the Compact Disc (CD). Secondly, the worksheet consists of a course grid, earning objective, language note, pre-activity, whilstactivity, and post-activity. This worksheet has been developed based on the principle of listening material development, namely, relevance and transferability/acceptability. Relevance means the worksheet connected with real-life student's things. Since the activities are realistic, this worksheet can be used in other classes and/or in out-of-school settings. The knowledge provided by the author's listening materials can be used by students outside of the classroom. This worksheet also discusses the Indonesian cultures, and it is supported by some listening tips in every unit.

The authors suggested the students practice more to comprehend each material delivered by the lecturer and to upgrade their listening skills through this worksheet. Then, the lecturer also should deliver the listening materials creatively by modifying the listening materials and making the learning process more interesting. Meanwhile, the other researchers are also expected to design listening worksheets from the basic level to the highest level of listening. So the students will study listening skills completely.

\section{REFERENCES}

Adnan, A. (2014). Listening material development: problems and challenges: A case of 'PPG SM-3T' at Universitas Negeri Padang. The 3rd UAD TEFL International Conference 2014.

Ahmadi, S. M. (2016). The Importance of listening in language learning. International Journal of Research in English Education, 1(1), 1-4.
Amila W, A., Abdurrahman, Suyatna, A., Distrik, I. W., \& Herlina, K. (2018). Practicality and effectiveness of student' worksheets based on ethno science to improve conceptual understanding in rigid body. International Journal of Advanced Engineering, Management and Science (IJAEMS), 4(5), 1-8.

Asemota, H. E. (2015, July). Nature, importance and practice of listening skill. British Journal of Education. 3(7), 1-7.

Asmawati, E. Y. S. (2015). Lembar Kerja Siswa (LKS) menggunakan model guided inquiry untuk meningkatkan keterampilan berpikir kritis dan penguasaan konsep siswa. Jurnal Pendidikan Fisika, 3(1), 1-16.

Bingol, M. A., Celik, B., Yildiz, N., \& Mart, C. T. (2014). Listening Comprehension difficulties encountered by students in second language learning class. Journal of Educational and Instructional Studies in the World, 4(1), 1-6.

Calderhead, W. J., Filter, K. J., \& Albin, R. W. (2006). An investigation of incremental effects of interspersing math items on taskrelated behavior. Journal of Behavioral Education, 15(1), 51-65.

Chothimah, D. H. (2014). Pengembangan Bahan Ajar LKS Mendengarkan Berbasis Media Audio Untuk Siswa Kelas VII SMP (Kurikulum 2013). Bengkulu University.

DeVito, J. A. (2012). Human Communication: The Basic Course, 14th ed. Hunter College of the City. University of New York.

Flowerdew, J., \& Miller, L. (2005). Second Language Listening: Theory and Practice. Cambridge: Cambridge University Press.

Firdaus, M. I. (2019). Listening Comprehension Strategies Used by EFL Students in State University of Surabaya. RETAIN Journal, 7(3), 1-9.

Gilakjani, A. P., \& Sabouri, N. P. (2016). Learners' listening comprehension difficulties in English Language Learning: A literature review. English Language Teaching, 9(6).

Hamdani. 2011. Strategi Belajar Mengajar. Pustaka Setia.

Hamouda, A. (2013). An Investigation of listening comprehension problems encountered by 
Saudi students in the listening classroom. International Journal of Academic. Research in Progressive Education and Development.

Ikhsan, M. K., \& Handayani, SB. (2016). The Development of Students' Worksheet Using Scientific Approach on Curriculum Materials. Paper presented at the Fourth International Seminar on English Language and Teaching.

Lee, C. (2014). Worksheet Usage, Reading Achievement, Classes' Lack of Readiness, and Science Achievement: A Cross-Country Comparison. International Journal of Education in Mathematics, Science and Technology, 2(2), 96-106.

Karim, C., \& Ciptaningrum, D. S. (2019). Developing Multimedia-Based Listening Materials for the Tenth Grade Students. ETERNAL Journal, 5(1), 1-12.

Kuswardani, T. C. L., Iksanuddin, \& Wardah. (2015). Designing Listening Materials Based On Contextual Teaching And Learning Approach. Jurnal Pendidikan dan Pembelajaran UNTAN, 4(11), 1-15.

Nawangsasi, E. (2015). Developing Listening Materials for the Eighth-Grade Students of SMPN 14 Yogyakarta Based On 2013 Curriculum. Unpublished Thesis. Yogyakarta: Universitas Negeri Yogyakarta.

Peraturan Menteri Pendidikan Nasional Nomor 23 Tahun 2007 Tentang Standar Kompetensi Lulusan.

Peterson, E. (2010). Internet-based Resources for Developing Listening. Studies in Self-Access Learning Journal, 1(2). 139-154.

Qodir, A., Bauhaqi, L., \& Miftah, M. Z. (2016). Developing Materials of Listening Comprehension for the English Department Students. Journal on English as a Foreign Language, 6(1), 1-18

Richard, J. C. (2011). Basic Tactics for Listening, 3rd Ed. New York: Oxford University Press.
Rotter, K. (2006). Creating Instructional Materials for All Pupils: Try COLA. Intervention in School and Clinic, 41(5), 273-282.

Sinaga, I. N., \& Fitriyani, T. (2019). Developing English Writing Materials in Narrative Text Based on Genre-Based Approach. Southeast Asia Language Teaching and Learning (SALTeL) Journal, 2(2), 1-6.

Sutedjo. (2006). Pengembangan Bahan Ajar dan Media.

https:/tedjo21.files.wordpress.com/2009/09/ pengembangan-materi-ajar-lpp-maret2008.pdf.

Syafi'i, M. L. (2016). Developing Listening Materials for the Tenth Graders. JEELS Journal, 3(1).

Syam, A. T. (2020). Developing Writing Module for the Fourth-Semester Learners of English Department at State Islamic Institute of Palopo. IJELTAL Journal, 5(1).

Tomlinson, B. (2011). Materials Development in Language Teaching. Cambridge: Cambridge University Press.

Tyagi, B. (2013). Listening: An Important Skill and Its Various Aspects. The Criterion: An International Journal in English, 12, 1-8.

Wilson, J. J. (2008). How to Teach Listening. USA: Longman.

Yıldırım, S., \& Yıldırım, Ö. (2016). The Importance of Listening in Language Learning and Listening Comprehension Problems Experienced by Language Learners: A Literature Review. Psychology, 16(4), 20942110.

Yulkifli, Ningrum, M. V., \& Indarsari, W. (2019). The Validity of Student Worksheet Using Inquiry-Based Learning Model with Science Process Skill Approach for Physics Learning of High School. JPPPF (Jurnal Penelitian dan Pengembangan Pendidikan Fisika), 5(2). 